\title{
Effects of Mild Mitral Valve Insufficiency, Sodium Intake, and Place of Blood Sampling on the Renin- Angiotensin System in Dogs
}

\author{
By H.D. Pedersen
}

Department of Clınıcal Studies, Small Anımal Hospıtal, The Royal Veterınary and Agrıcultural Unıversity, Frederıksberg, Denmark

Pedersen, H. D.: Effects of mild mitral insufficiency, sodium intake, and place of blood sampling on the renin-angiotensin system in dogs. Acta vet. scand. 1996, 37, 109-118. - In 23 Cavalıer King Charles Spaniels, 12 with mild mitral valve insufficiency (MVI) and 11 controls, the actıvity of the renın-angiotensin system (RAS) was assessed by measurıng the plasma renın activity (PRA) and plasma aldosterone concentration (PAC) in 5 different settings. The dogs were sampled at the clinic before the trial and thereafter at home and at the clinic; during both a period on control diet and a period on low sodium diet The dogs with mild MVI had the highest median PRA and PAC in all 5 settings. An analysis of variance accordingly showed that dogs with mild MVI had significantly higher PRA $(p<0.0001)$ and PAC $(p=003)$ than controls, and that the sodium intake and place of blood sampling did not significantly affect this finding. The sodium intake had highly significant effects on PRA and PAC, and the place of blood sampling had no significant effects on PRA and PAC. The activity of angiotensin-converting enzyme in serum was lower in dogs with mild MVI than in controls $(p=0.0002)$. The plasma levels of endothelın-1, atrial natruretıc peptıde, and argınıne vasopressin, 3 peptides of pathophysiologic importance in congestıve heart fallure, were not significantly changed by the disease.

The early activation of the RAS in dogs with MVI suggests that the valvular disease process itself might be the cause of the activation, but confirmation of this requires further studies

aldosterone; angiotensin-converting enzyme; arginine vasopressin; atrial natriuretic peptide; Cavalier King Charles Spaniels; endocardiosis; endothelin-1; heart disease; pathophysiology; plasma renin activity.

\section{Introduction}

The renin-angiotensin system (RAS) is important in the pathophysiology of congestive heart failure together with the sympathetic nervous system and peptides such as atrial natriuretic peptide (ANP), arginine vasopressin (AVP), and endothelin-1 (ET-1) (Francis 1990). The rate limiting step in the RAS is the release of renin from the juxtaglomerular cells in the kidney. Renin cleaves the decapeptide angiotensin
I of circulating angiotensinogen. Angiotensinconverting enzyme (ACE) then quickly converts angiotensin I to the octapeptide angiotensin II, the active component in the RAS. Angiotensin II is a potent vasoconstricting agent and an important acute stimulus for the synthesis of aldosterone in the adrenal glands. In a recent study, we found that clinically healthy Cavalier King Charles Spaniels (CKCS) without heart murmurs had a high 
plasma renin activity (PRA) and low plasma aldosterone concentration (PAC), and thus a much higher PRA to PAC ratio than dogs from 5 other breeds (Pedersen et al. 1995a). The CKCS breed is known to be highly predisposed to mitral valvular insufficiency (MVI) due to chronic valvular disease (CVD) (Thrusfield et al. 1985, Darke 1987, Häggström et al. 1992, Beardow \& Buchanan 1993), and a large proportion of young CKCS without heart murmurs has been found to have echocardiographic signs of early mitral valvular disease (Pedersen et al. 1995b). It is therefore possible that the high PRA to PAC ratio found in CKCS in the aforementioned study might have been associated with developing CVD. The theory that CVD is associated with changes in the RAS is supported by a recent study showing that CKCS with asymptomatic and mildly symptomatic MVI have higher PRA and PAC than CKCS without MVI (Pedersen et al. 1995c). This finding was in contrast to the low-normal activity of the systemic RAS that is usually found in mild or stable heart failure in humans (Nicholls 1993). It could be speculated that the dogs with MVI in the above-mentioned study might have had a RAS activity more like the controls if they had been sampled in a home setting and thus had avoided the "exercise" of being transported to the clinic (Pedersen et al. 1995c). Human patients with mild untreated congestive heart failure have been reported to have a greater rise in PRA during exercise than control subjects (Kirlin et al. 1986). Another factor with a large potential to influence the RAS is the sodium intake (Davis \& Freeman 1976). It is not known whether a reduction in sodium intake will result in the same increase in RAS activity in dogs with mild MVI as in controls.

The present study aimed to evaluate the effects of mild MVI, place of blood sampling (home versus clinic), and sodium intake (normal versus low) on the RAS in CKCS. Endothelin-1,
ANP, and AVP were also measured in dogs with mild MVI and in controls.

\section{Materials and methods \\ Dogs}

Twenty-three CKCS were included in the study. Before entering the study, all the dogs were examined clinically, and with electrocardiography and echocardiography, and dogs with a systolic murmur also had thoracic radiography. It was found that none of the CKCS showed signs of other heart diseases than CVD, that 12 of the dogs ( 4 males and 8 females) had MVI, and that 11 (3 males and 8 females) were without heart murmur. Of the dogs with MVI, 10 were asymptomatic, and 2 were mildly symptomatic with a history of coughing. The left atrium to aortic root ratio (LA/Ao) was measured from short axis 2-D echocardiograms taken at the aortıc valve level as described by Häggström et al. (1994). Baseline characteristics with respect to age, weight, heart rate, and different echocardiographic measurements are shown in Table 1

Table 1. Baseline characteristics of 23 Cavalier King Charles Spaniels, 11 controls and 12 with mild mitral valve insufficiency (MVI) enrolled in the study (mean \pm SD)

\begin{tabular}{lcc}
\hline & Controls & \multicolumn{1}{c}{ MVI } \\
\hline Age (years) & $4.7 \pm 1.7$ & $68 \pm 2.2^{*}$ \\
Weight (kg) & $9.5 \pm 1.2$ & $9.6 \pm 1.7$ \\
Heart rate (beats/min) & $129 \pm 24$ & $123 \pm 12$ \\
LVEDD (mm) & $266 \pm 1.4$ & $28.2 \pm 3.3$ \\
LVESD (mm) & $185 \pm 1.6$ & $19.0 \pm 24$ \\
$\Delta D(\%)$ & $307 \pm 4.8$ & $32.5 \pm 43$ \\
LA $/$ Ao ratio & $1.2 \pm 0.2$ & $10 \pm 02$ \\
& & \\
\hline
\end{tabular}

LVEDD = left ventricular end-diastolic diameter; LVESD = left ventricular end-systolic diameter, $\Delta D=$ fractional shortening of the left ventricle; $\mathrm{LA} / \mathrm{Ao}$ ratio $=$ ratio of the the left atrium to aortic root diameter; $*=$ significantly different from controls $(\mathrm{p}<0.05)$. 
for dogs with and without MVI. All the dogs in the study had no or only slight enlargement of the left atrium $(\mathrm{LA} / \mathrm{Ao}<1.5)$. None of the dogs with MVI had signs of congestion or edema on thoracic radiographs. The dogs received no medication 4 weeks prior to or during the study. Hematological and biochemical analyses of blood samples of the dogs prior to the experiment revealed no abnormalities, and none of the dogs showed signs of diseases other than MVI.

\section{Protocol}

After the initial examination at the clinic, all dogs were given a canned control diet for 3 weeks followed by a 3-week period on a canned low sodium diet (WALTHAM Veterinary Diet Canine Low Sodium. MF, Austria). The control diet was made by adding sodium chloride to half the batch of low sodium diet just before it was canned. Hence only the content of sodium chloride differed between the two diets. The low sodium diet contained $0.09 \mathrm{~g} \mathrm{Na}^{+}$per 400 Kcal metabolizable energy and the control diet contained $0.51 \mathrm{~g} \mathrm{Na}^{+}$per $400 \mathrm{Kcal}$. At the initial examination at the clinic, blood samples for analysis of PRA, PAC and serum ACE activity (S-ACE) were taken. Five to 8 days into both 3-week periods, blood samples for analysis of PRA, PAC and S-ACE were taken in a home setting. At the end of each three-week period, blood samples for analysis of PRA, PAC, S-ACE, ET-1, ANP and AVP were taken at the clinic.

\section{Sample collection and analytic procedures}

All samples were collected after an overnight fast by the same people between 09.00 am and $11.00 \mathrm{am}$. The samples were taken by cephalic venipuncture with the dogs in a sitting position, and great care was taken to minimize stress during the procedure. All samples were taken during the initial examination after the dog had been given time to acclimatize. Furthermore, the owner was present next to the head of the dog to calm it. Blood for PRA and PAC determination was drawn into iced EDTA-containing tubes (Vacutainers ${ }^{\circledR}$, Becton-Dickinson) and centrifuged at $4{ }^{\circ} \mathrm{C}$ within one and a half hours. The plasma was kept at $-20^{\circ} \mathrm{C}$ until analysis. PRA was assayed with a radioimmunoassay based on angiotensin I trapping by antibody as described by Poulsen \& Jørgensen (1974). The PAC was determined with a RIA-kit (CoatA-Count ${ }^{\circledR}$, Diagnostic Products Corporation). All measurements were done in duplicate. The serum angiotensin-converting enzyme activity (S-ACE) was measured spectrophotometrically with a kit (Angiotensin Converting Enzyme $(\mathrm{ACE})^{\circledR}$, Sigma), applied to a Cobas Fara ${ }^{\circledR}$ (Roche) centrifugal analyser (Jensen \& Koch 1992).

Blood samples for the determination of ET-1, ANP and AVP were collected into iced $5 \mathrm{ml}$ polyethylene tubes containing EDTA $(25 \mu \mathrm{mol})$ and aprotinin (Novo Nordısk, Denmark) (2700 $\mathrm{KIU})$ and centrifuged at $4{ }^{\circ} \mathrm{C}$ withın an hour. The plasma was kept at $-20^{\circ} \mathrm{C}$ unt1l analysis. The 3 peptides were measured as described elsewhere (Schütten et al. 1987, Emmeluth \& Bie 1992, Emmeluth et al. 1994).

\section{Statistical analyses}

PRA and PAC data are expressed in medians and interquartile intervals (25-75 percentile) since the Shapiro-Wilk test indicated that the values were not distributed in a Gaussian manner. To evaluate the effects of disease status, sodium intake, place of bloodsampling, and individual dog (within disease status group) on PRA, PAC, and S-ACE, a 4-way analysis of varrance was performed on the values obtained in the 4 settings in which the dogs were on a controlled diet. The residuals were tested for normality and homogeneity of variance using the Shapiro-Wilk test and residual plots, respec- 


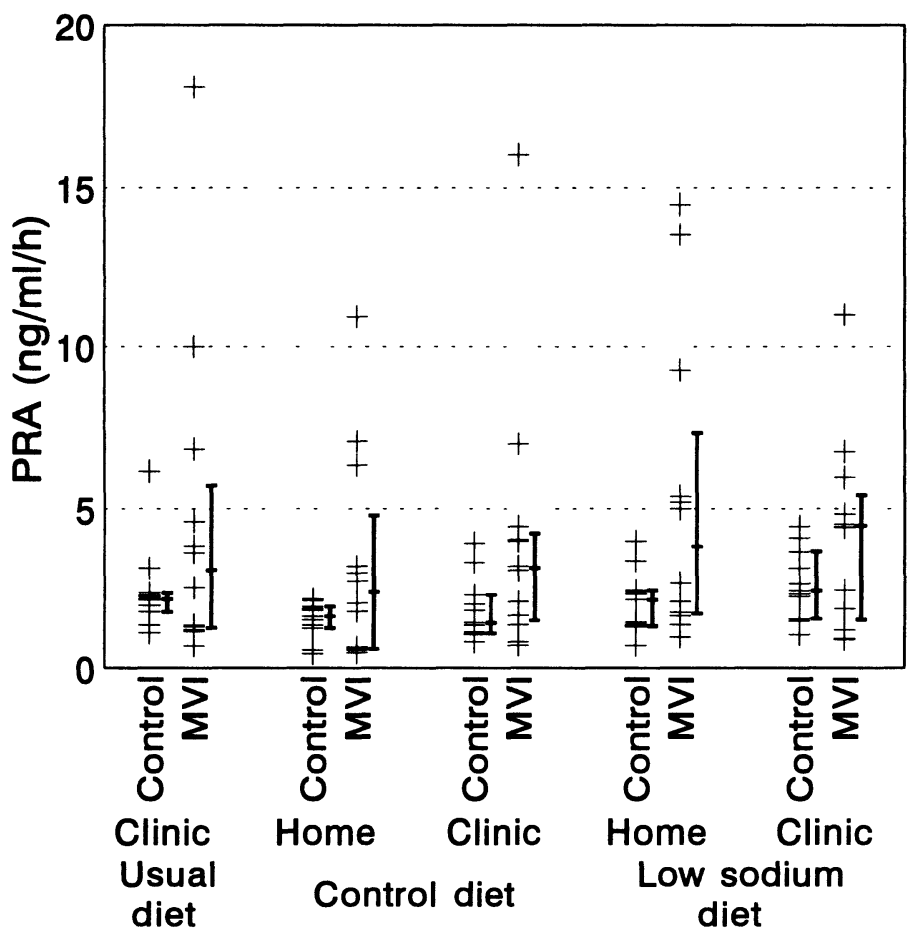

Figure 1. Plasma renın activity (PRA) in 23 Cavalıer Kıng Charles Spaniels: 12 with mild mitral valve insufficiency (MVI) and 11 controls. The dogs were examined under 5 different circumstances with respect to place of blood sampling and diet.

tively. To obtain normality and homogeneity of variance in the PRA, PAC, and S-ACE values, logarithmic transformations were performed before analyses. To compare the ET-1, ANP and AVP values obtained at the end of the first 3week period with the ones obtained at the end of the second period, a paired Students t-test was used. To compare controls with diseased dogs with respect to the same 3 peptides an unpaired Students t-test was used. Changes were considered to be statistically significant when $\mathrm{p}<0.05$.

\section{Results}

The PRA, PAC, and S-ACE values found in the 5 different settings are shown in Fig. 1, 2, and 3, respectively. It appears that the dogs with mild MVI had higher median PRA and median PAC than the controls in all 5 settings. In accordance with this, the analysis of variance showed a significant difference between dogs with mild MVI and controls both with respect to PRA $(p<0.0001)$ and PAC $(p=0.03)$. The sodium intake was also found to have a significant effect on PRA $(p=0.0003)$ and PAC $(p<0.0001)$. The median PRA of the controls increased from $1.57 \mathrm{ng} / \mathrm{ml} / \mathrm{h}$ to $2.34 \mathrm{ng} / \mathrm{ml} / \mathrm{h}$, and the median PRA of the dogs with MVI increased from 2.87 $\mathrm{ng} / \mathrm{ml} / \mathrm{h}$ to $4.44 \mathrm{ng} / \mathrm{ml} / \mathrm{h}$ as a response to the low sodium diet. The median PAC increased more in response to the reduced sodium intake: from $16.5 \mathrm{pg} / \mathrm{ml}$ to $136 \mathrm{pg} / \mathrm{ml}$ in the controls, and 


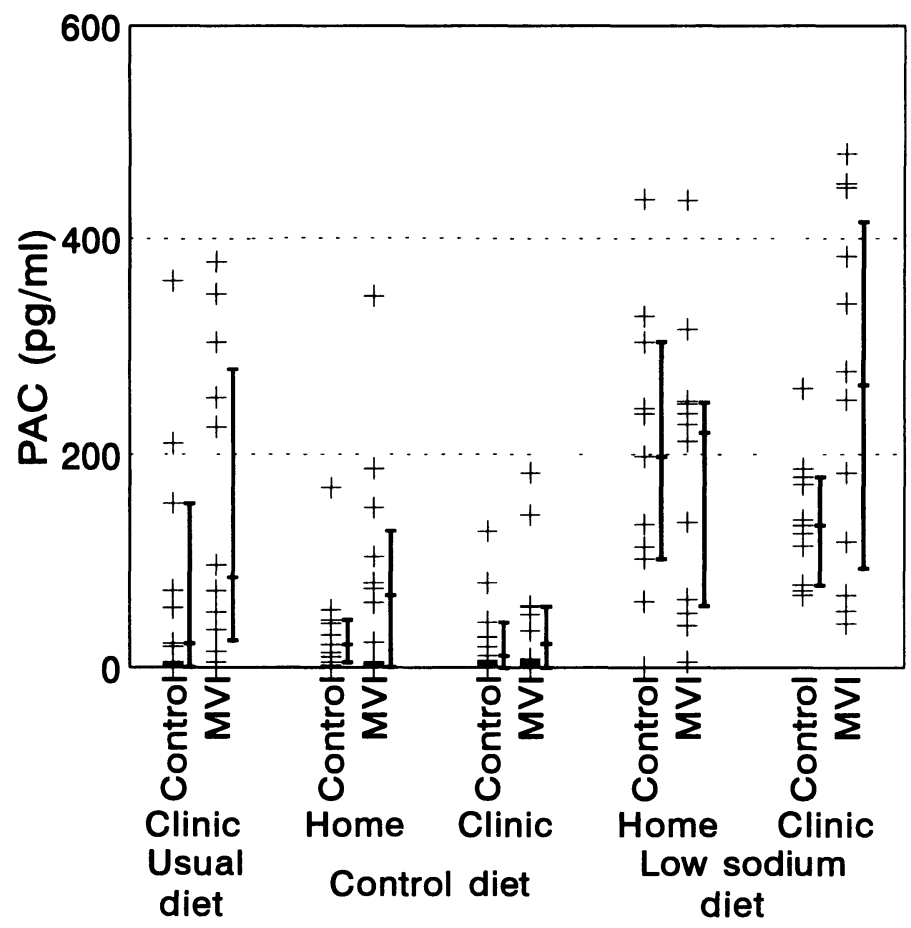

Figure 2. Plama aldosterone concentration (PAC) in 23 Cavalier King Charles Spaniels: 12 with mild mitral valve insufficiency (MVI) and 11 controls. The dogs were examined under 5 different circumstances with respect to place of blood sampling and diet. The values from each dog are presented together with medians and 25 to 75 interquartile intervals.

from 41.5 to $232 \mathrm{pg} / \mathrm{ml}$ in the dogs with MVI. The place of blood sampling was found to have no significant effect on PRA $(p=0.11)$ and PAC $(p=0.53)$. Interactions between disease status and sodium intake, between disease status and place of blood sampling, and between sodium intake and place of blood sampling were found to have no significant effects on PRA and PAC. The inter-individual variation contributed significantly to the overall variation with respect to both PRA $(p<0.0001)$ and PAC $(p<0.0001)$. The percentage of the total sum of squares that were accounted for by the model (the R-square of the model) was $77 \%$ in the case of both PRA and PAC.

The dogs with mild MVI had a lower median S-
ACE than the controls in all 5 settings (Fig. 3). The analysis of variance accordingly showed that disease status had a significant effect on $\mathrm{S}$ $\operatorname{ACE}(p=0.0002)$. The place of blood sampling had no significant effect on S-ACE $(p=0.50)$, but the sodium intake had a significant effect, with lower S-ACE values being measured during the low sodium period $(p=0.01)$. The interindividual variation was significant also in the case of S-ACE $(p=0.002)$.

The sodium intake was found to have no significant effect on ET-1, ANP, and AVP, neither in dogs with mild MVI nor in controls. In addition, the dogs with mild MVI were not significantly different from the controls with respect to either ET-1 (3.71 pg/ml vs. $2.94 \mathrm{pg} / \mathrm{ml}$, 


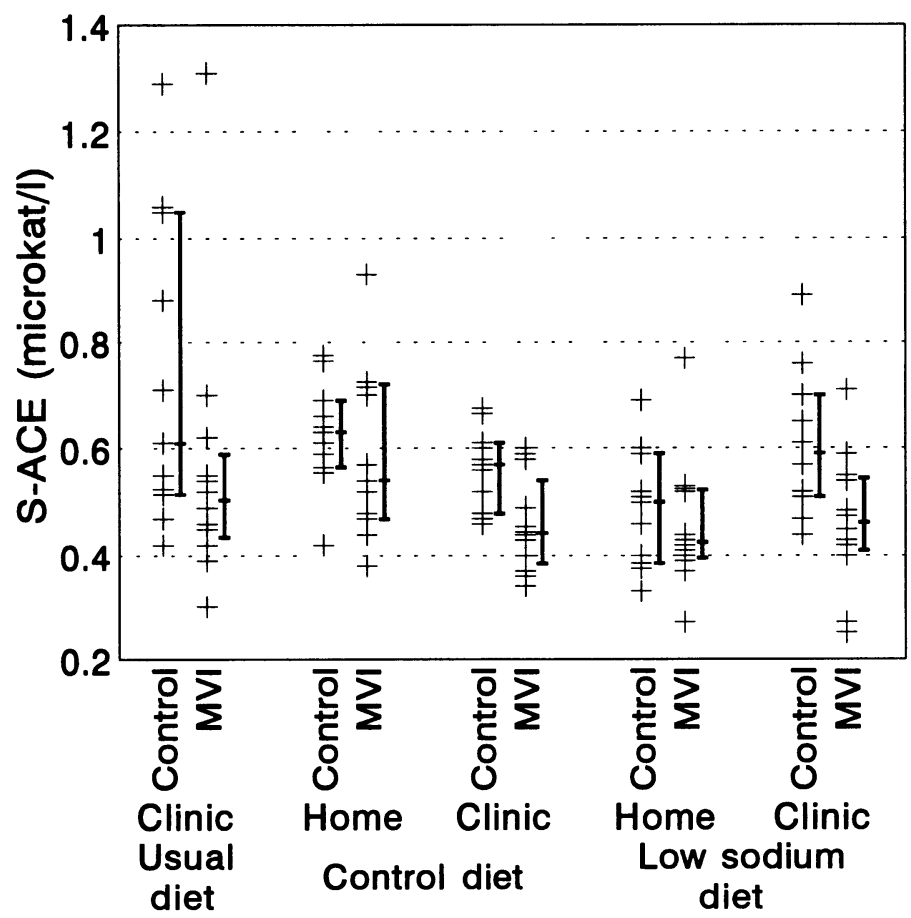

Figure 3. Serum angiotensın-convertıng enzyme actıvity (S-ACE) in 23 Cavalier King Charles Spaniels: 12 with mild mitral valve insufficiency (MVI) and 11 controls. The dogs were examined under 5 different circumstances with respect to place of blood sampling and diet The values from each dog are presented together with medians and 25 to 75 interquartıle intervals.

$\mathrm{p}=0.16)$, ANP $(43.9 \mathrm{pg} / \mathrm{ml}$ vs. $44.3 \mathrm{pg} / \mathrm{ml}$, $\mathrm{p}=0.93)$, or AVP (4.02 pg/ml vs. $3.80 \mathrm{pg} / \mathrm{ml}$, $\mathrm{p}=0.50)$.

\section{Discussion}

The present study shows that the PRA and PAC are increased and that the S-ACE is decreased in dogs with mild MVI. The sodium intake was found to have significant effects on the RAS in itself but not in interaction with disease status. The place of blood sampling was found to have no significant effects on the RAS, neither in itself, nor in interaction with disease status.

Attempts were made in the present study to keep the total variation in the data as low as pos- sible. All the dogs were untreated dogs from one breed, and all dogs were fed the same diet. In addition, all blood samples were taken in exactly the same way each time by the same people. Still, only $77 \%$ of the total variation in the PRA and PAC data could be accounted for by the statistical model used for the analyses of variance. This, however, is probably as good as can be expected since both renin and aldosterone are known to have a predominantly burstlike mode of secretion (Vieweg et al. 1992).

The present study shows that our previous finding of an activated RAS in CKCS with asymptomatic and mildly symptomatic MVI holds true when the sodium intake of the dogs is controlled (Pedersen et al. 1995c). In addition, it is 
shown in a more unambiguous way here than in the aforementioned study that the RAS is activated early on in the course of the disease. The dogs with MVI seemed to be little different from the controls with respect to heart rate and dimensions of the left ventricle and left atrium (Table 1), and furthermore, 10 of the 12 dogs were asymptomatic. The fact that neither sodium intake nor place of blood sampling interacted with disease status suggests that the finding of high RAS activity in dogs with mild MVI is robust. No setting seemed to be better suited than the rest to detect a difference between dogs with MVI and controls.

The median PRA and PAC values found at the clinic when the dogs entered the study are in good accordance with values found previously in CKCS dogs under similar circumstances (Pedersen et al. 1995c). Feeding the dogs 2 different sodium levels disclosed, as expected, that the sodium intake has highly significant effects on PRA and PAC. A difference, however, was found in the response of the 2 hormones to a reduced sodium intake. The PAC increased more than the PRA, resulting in a higher PAC to PRA ratio during the low sodium period both in diseased and control dogs. A similar observation was made when the same diets were used to study the RAS in Beagles, and as discussed in that study, it is likely that the shift in PAC to PRA ratio is due to the high potassium relative to sodium content of the diets (Pedersen et al. 1994a). Compared to the Beagles in that study, it appears that the controls in the present study have higher PRA and lower PAC. The same finding of a high PRA and low PAC in CKCS was also made when CKCS was compared with 5 other breeds with respect to PRA and PAC (Pedersen et al. 1995a).

The level of RAS activity has been found to correlate well with clinical state in humans with congestive heart failure (Dzau et al. 1981). In untreated humans with asymptomatic left ven- tricular dysfunction, the PRA has been found to be the same as in controls (Francis et al. 1990). In dogs with experımentally-induced heart failure it has also been shown that the activity of the RAS correlates well with the degree of circulatory impairment (Watkins et al. 1976). The present findings of an increased RAS activity in dogs with mild disease suggests that a mechanism other than impaired circulation could be responsible for the increased RAS activity. The fact that the dogs in this study had no or only slight enlargement of the left atrium suggests that they had a small regurgitation, and it does not seem likely that many of these dogs needed an activated RAS to maintain blood pressure. The aforementioned finding of a high PRA to PAC ratio in the highly predisposed CKCS breed prompted us to suggest that a defect or dysregulation in the RAS might be associated with developing CVD (Pedersen et al. 1995a). A reason for advancing this hypothesis was that mitral valve prolapse (MVP) in humans is known to be associated with a neuroendocrine or autonomic dysfunction in many cases (Coglan 1988, Boudoulas et al. 1989), and that we found MVP in the majority of young CKCS without heart murmurs (Pedersen et al. 1995b). The findings in the present study supports the hypothesis that developing CVD is associated in some way with changes in the RAS. Autoradiographic studies of rat hearts in vitro supports the concept that the RAS might have effects on valve leaflets. It has been found that a high density of ACE and a low density of angiotensin II receptors is present in valve leaflets (Pinto et al. 1991, Yamada et al. 1991, Sun et al. 1994). Future autoradiographic studies might clarify whether the RAS is involved in the degenerative changes of the leaflets found in CVD in dogs.

The finding of a significantly lower S-ACE in dogs with mild MVI than in controls suggests that low activity of this enzyme is associated 
with the disease process. Further supporting this is the finding that normal Beagles have higher S-ACE than the controls in this study (Pedersen et al. 1994a). In 3-year-old Beagles without heart murmurs, we have previously shown that only 1 out of 15 had echocardiographic signs of early mitral valve abnormalities as compared with 13 out of 15 age- and sex-matched CKCS without murmurs (Pedersen et al. 1995b). Among dogs without heart murmurs, the Beagles can thus be considered to have less developing CVD than the controls in this study. An insertion/deletion polymorphısm in the ACE gene has been shown to account for nearly half the variation in S-ACE among people (Rigat et al. 1990). This polymorphism has been shown to be a risk factor for different heart diseases in man including myocardial infarction and dilated cardiomyopathy (Cambien et al. 1992, Raynolds et al. 1993). Whether such a polymorphism exists in dogs and whether it might be a risk factor for CVD in dogs remains to be investigated.

The dogs with mild MVI in this study were not significantly different from controls with respect to ET-1. This supports that the dogs with MVI had little circulatory impairment since plasma levels of ET-1 are known to correlate with pulmonary capillary wedge pressure (Vollmar 1992). With respect to ANP and AVP, it was also found that there was no significant difference between dogs with mild MVI and controls. Häggström et al. (1994) have previously shown that ANP is not increased in dogs with mild MVI. The present findings confirm this and furthermore show that an increase of plasma AVP in dogs with mild MVI is not to be expected either. These findings with respect to ANP and AVP are in contrast to findings in humans with asymptomatic heart disease. Significantly higher levels of ANP and AVP have been found in untreated humans with asymptomatic left ventricular dysfunction (Francis et al.
1990). Whether this difference is due to species specific differences in the neuroendocrine response to asymptomatic heart disease or whether it is related to the different disease etiology is not known. The atria might have been more dilated in the humans with asymptomatic left ventricular dysfunction than in the dogs with MVI in the present study. This might explain the difference with respect to ANP since atrial stretch is known to be the main stimulus for ANP release (DeBold et al. 1991, Häggström et al. 1994). The lack of effect of sodium intake on ET-1, ANP, and AVP has previously been reported in normal Beagles (Pedersen et al. 1994b). Based on the results presented here, it seems that the same is true for CKCS irrespective of whether or not they have mild MVI. In conclusion, the present study shows that dogs with mild MVI have higher PRA and PAC, and lower S-ACE than controls, and that the sodium intake and place of blood sampling does not significantly affect this finding. The sodium intake greatly influences PRA and PAC, but the place of blood sampling seems to have insignificant influence on PRA and PAC. The early activation of the RAS in dogs with MVI suggests that the valvular disease process itself might be the cause of the activation, but confirmation of this hypothesis requires further studies.

\section{Acknowledgements}

The author wish to thank Professor Knud Poulsen, Department of Anatomy and Physiology, The Royal Veterınary and Agricultural Unıversity (RVAU) for providing laboratory facilities and reagents for the measurement of PRA. Associated professor Peter Bie, Department of Medical Physiology, Unıversity of Copenhagen is gratefully acknowledged for measuring ET-1, ANP and AVP. Assistant professor Annette Ersbøll, Department of Mathematics and Physics, RVAU is acknowledged for assisting with the statistical analyses. The excellent technical assistence of Ms Karın Faber and Mrs Susannne Holm Kristiansen, Department of Anatomy and Physiol- 
ogy, RVAU is highly appreciated. WALTHAM Centre for Pet Nutrition, Leicestershire, England is acknowledged for providing the diets. The study was supported by the Danish Agricultural and Veterinary Research Council project No. 13-4661 and 9400437, and by the Novo Nordic Fund.

\section{References}

Beardow AW, Buchanan JW Chronic mitral valve disease in Cavalier King Charles Spaniels: 95 cases (1987-1991). J. Amer Vet. Med. Assoc. 1993, 203, 1023-1029

Boudoulas H, Kolıbash AJ, Baker P, King BD, Wooley $C F$ Mitral valve prolapse and the mitral valve prolapse syndrome A diagnostic classification and pathogenesis of symptoms. Amer Heart J. 1989, 118, 796-818.

Cambien F, Poirler O, Lecerf L, Evans A, Cambou J, Arveller D, Luc G, Bard J, Bara L, Ricard S, Tiret $L$, Amouyel P, Alhenc-Gelas F, Soubrier F Deletion polymorphism in the gene for angiotensinconverting enzyme is a potent risk factor for myocardial infarction. Nature 1992, 359, 641644.

Coghlan HC Autonomic dysfunction in the mitral valve prolapse syndrome. The brain-heart connection and interaction In: Boudoulas H, Wooley $\mathrm{CF}$, eds. Mitral valve prolapse and the mitral valve prolapse syndrome Mount Kisco, NY Futura Publishing Company, Inc, 1988, 389-426.

Darke $P G G$ Valvular incompetence in Cavalier Kıng Charles Spaniels. Vet Rec 1987, 120, 365366.

Davis JO, Freeman $R H$ Mechanısms regulatıng renın release. Physiological Reviews 1976, 56, 1-56

DeBold AJ, Kurosk-DeBold ML, Boer PH, Dubé G, Mangat $H$, Johnson $F$. A decade of atrial natriuretic factor research Can J Physiol. Pharmacol. 1991, 69, 1480-1485.

Dzau VJ, Coluccı WS, Hollenberg NK, Willıams GH. Relation of the renin-angiotensin-aldosterone system to clinical state in congestive heart failure Circulation 1981, 63, 645-651

Emmeluth $C$, Bie P. Effects, release and disposal of endothelin-1 in conscious dogs. Acta Physiol. Scand. 1992, 146, 197-204.

Emmeluth C, Drummer C, Gerzer R, Bie P. Natriuresis in conscious dogs caused by increased carotid $\left[\mathrm{Na}^{+}\right]$during angiotensin II and aldosterone blockade. Acta Physiol Scand. 1994, 151, 403-411
Francis GS. Neuroendocrine activity in congestıve heart fallure. Amer. J. Cardiol 1990, 66, 33D$39 D$.

Francis GS, Benedict C, Johnstone DE, Kirlın PC, Nicklas J, Liang C, Kubo SH, Rudın-Toretsky E, Yusuf $S$. Comparison of neuroendocrine activation in patients with left ventricular dysfunction with and without congestive heart failure. A substudy of the studies of left ventricular dysfunction (SOLVD) Circulation 1990, 82, 17241729.

Häggström J, Hansson $K$, Kvart C, Swenson L. Chronic valvular disease in the Cavalier King Charles Spaniel in Sweden. Vet. Rec. 1992, 131, 549-553

Haggström J, Hansson K, Karlberg BE, Kvart $C$, Olsson $K$ Plasma concentration of atrial natriuretic peptide in relation to severity of mitral regurgitation in Cavalier King Charles Spaniels. Amer. J. Vet. Res. 1994, 55, 698-703

Jensen $A L$, Koch $J$ Determination of angiotensin convertıng enzyme in canıne serum. Clin Chem Enzym. Comms. 1992, 4, 311-317.

Kırlın PC, Grekın R, Das S, Ballor E, Johnson T, Pıtt $B$ Neurohumoral activation during exercise in congestive heart failure. Amer. J. Med. 1986, 81, 623-629

Nicholls MG and Riegger AJG Renin in cardiac failure. Chapter $76 \mathrm{in} \cdot$ Robertson JIS and Nicholls MG (eds.) The renın-angiotensin system. Gower Medical Publishing, London, 1993.

Pedersen HD, Koch J, Jensen AL, Poulsen K, Flagstad $A$ Some effects of a low sodium diet high in potassium on the renin-angiotensin system and plasma electrolyte concentrations in normal dogs. Acta vet scand. 1994a, 35, 133-140

Pedersen HD, Koch J, Bie P, Jensen AL, Flagstad A Effects of a low sodium diet with a high potassium content on plasma endothelın-1, atrial natriuretic peptide and argınıne vasopressin in normal dogs J. Vet Med. A. 1994b, 41, 713-716

Pedersen HD, Olsen LH, Arnorsdottır $H$ Breed differences in the plasma renin activity and plasma aldosterone concentration of dogs. J. Vet Med A 1995a, 42, 435-441.

Pedersen HD, Kristensen BØ, Lorentzen KA, Koch J, Jensen $A L$, Flagstad $A$ Mitral valve prolapse in 3-year-old healthy Cavalier King Charles Span1els. An echocardiographic study. Can. J. Vet Res. 1995b, 59, 294-298.

Pedersen HD, Koch J, Poulsen K, Jensen AL, Flagstad $A$ Activation of the renin-angiotensin 
system in dogs with asymptomatic and mildly symptomatic mitral valvular insufficiency. J. Vet. Int. Med 1995c, 9, 328-331.

Pinto JEB, Viglione P, Saavedra JM Autoradiographic localization and quantification of rat heart angiotensin convertıng enzyme. Amer J Hypertens. 1991, 4, 321-326.

Poulsen K, Jørgensen J: An easy radioummunolog1cal microassay of renin activity, concentration and substrate in human and anımal plasma and tissues based on angiotensin I trapping by ant1body. J Clın. Endocrinol. Metab. 1974, 39, 816825.

Raynolds MV, Bristow MR, Bush EW, Abraham WT, Lowes BD, Zlsman LS, Taft CS, Perryman MB. Angiotensin-convertıng enzyme DD genotype in patients with ischaemic or idiopathic dilated cardiomyopathy. Lancet 1993, 342, 1073-1075.

Rigat B, Hubert C, Alhenc-Gelas F, Cambien F, Corvol $P$, Soubrier $F$. An insertion/deletion polymorphism in the angiotensin I-converting enzyme gene accounting for half the variance of serum enzyme levels J. Clın. Invest. 1990, 86, 13431346.

Schutten HJ, Johannessen AC, Torp-Pedersen C, Sander-Jensen $K$, Bie P, Warberg $J$ Central venous pressure - a physiological stımulus for secretion of atrial natriuretic peptide in humans? Acta Physiol. Scand. 1987, 131, 265-272

Sun Y, Diaz-Arias AA, Weber KT Angiotensin-convertıng enzyme, bradykının, and angiotensin II receptor binding in rat skin, tendon, and heart valves: An in vitro, quantitative autoradiographic study J Lab. Clın Med. 1994, 123, 372-377

Thrusfield MV, Attken CGG, Darke PGG Observations on breed and sex in relation to canine heart valve incompetence. J Small Anım. Pract. 1985, 26, 709-717.

Vleweg WVR, Veldhuls JD, Carey RM Temporal pattern of renin and aldosterone secretion in men: effects of sodium balance. Am J Physiol. 1992, 262, F871-F877.

Vollmar AM Endothelıns. J. Vet. Med A 1992, 39, 481-493

Watkins L Jr, Burton JA, Haber E, Cant JR, Smith FW,
Barger $A C$ The renin-angiotensin-aldosterone system in congestive failure in conscious dogs. J. Clin. Invest. 1976, 57, 1606-1617

Yamada H, Fabris B, Allen AM, Jackson B, Johnston $C I$, Mendelsohn FAO Localization of angiotensin convertıng enzyme in rat heart. Circ. Res. $1991,68,141-149$

\section{Sammendrag}

Effekter af mild mitralinsufficiens, natrium indtag og sted for blodprøvetagning på renin-angiotensin systemet hos hund

I denne undersøgelse blev aktıviteten af renin-angiotensin systemet (RAS) bedømt på 12 Cavalier Kıng Charles Spaniels med mild mitralinsufficiens (MVI) og på 11 kontroller af samme race, ved at måle plasma renın aktıviteten (PRA) og plasma aldosteron koncentrationen (PAC) 5 gange Første målıng var ved forsøgets start, og derefter blev hundene målt såvel hjemme som på klınikken: Først under en perıode på kontroldıæt, og dernæst under en perıode på lav-salt dıæt. Medianværdıerne for PRA og PAC var højere hos hundene med MVI end hos kontrollerne ved alle 5 blodprøvetagninger I overensstemmelse hermed viste en variansanalyse, at hundene med MVI havde signifikant højere PRA $(p<00001)$ og PAC $(p=0.03)$ end kontrollerne, og at hverken stedet hvor blodprøverne blev taget eller diæten havde signifikant indflydelse på dette fund Diæten, og dermed natrium indtaget, havde en signifikant indflydelse på PRA ( $p=0$ 0003) og PAC ( $<<0.0001)$, mens stedet hvor blodprøverne blev taget ingen signifikant effekt havde Serumkoncentrationerne af angıotensinkonverterende enzym var lavere hos hundene med MVI end hos kontrollerne $(p=0.0002)$ Plasmaniveauerne af endotelın-1, atrialt natriuretısk peptıd og vasopressin, der alle har patofysiologisk betydning ved kongestıv hjerteınsufficiens, var ıkke signıfikant ændrede hos hunde med lavgradig MVI.

Den tidlige aktıverıng af RAS hos hunde med MVI kunne tyde på, at selve sygdomsprocessen 1 klapperne er associeret med stigningen. Yderligere undersøgelser er nødvendige for at bevise dette.

(Recelved September 20, 1995; accepted November 8, 1995)

Reprints may be obtained from: H. D. Pedersen, Department of Anatomy and Physiology, Section for Veterinary Physiology and Biochemıstry, The Royal Veterınary and Agricultural Unıversity, Bülowsvej 13, DK-1870 Frederiksberg C, Denmark. 